\title{
Spinal Hydatid Cyst Disease : Challenging Surgery - an Institutional Experience
}

\author{
Yusuf Sukru Caglar, M.D., Onur Ozgural, M.D., Murat Zaimoglu, M.D., Cemil Kilinc, M.D., Umit Eroglu, M.D., \\ Ihsan Dogan, M.D., Gokmen Kahilogullari, M.D., Ph.D. \\ Department of Neurosurgery, Ankara University School of Medicine, Ankara, Turkey
}

Objective : Hydatid cyst disease is caused by the parasite Echinococcus granulosus. It is rarely seen in the vertebral system, occurring at a rate of $0.2-1 \%$. The aim of this study is to present 12 spinal hydatid cyst cases, and propose a new type of drainage of the cyst.

Methods : Twelve cases of spinal hydatid cysts, surgical operations, multiple operations, chronic recurrences, and spinal hydatic cyst excision methods are discussed in the context of the literature. Patients are operated between 2005 and 2016. All the patients are kept under routine follow up. Patient demographic data and clinicopathologic characteristics are examined.

Results : Six male and six female patients with a median age of 38.6 at the time of surgery were included in the study. Spinal cyst hydatid infection sites were one odontoid, one cervical, five thoracic, two lumbar, and three sacral. In all cases, surgery was performed, with the aim of total excision of the cyst, decompression of the spinal cord, and if necessary, stabilization of the spinal column. Mean follow up was 61.3 months (10-156). All the patients were prescribed Albendazole. Three patients had secondary hydatid cyst infection (one lung and two hepatic).

Conclusion : The two-way drainage catheter placed inside a cyst provides post-operative chlorhexidine washing inside the cavity. Although a spinal hydatid cyst is a benign pathology and seen rarely, it is extremely difficult to achieve a real cure for patients with this disease. Treatment modalities should be aggressive and include total excision of cyst without rupture, decompression of spinal cord, flushing of the area with scolicidal drugs, and ensuring spinal stabilization. After the operation the patients should be kept under routine follow up. Radiological and clinical examinations are useful in spotting a recurrence.

Key Words : Spinal cystic echinococcosis · Surgery · Management.

\section{INTRODUCTION}

Hydatid cyst disease is caused by the parasite Echinococcus granulosus and occurs mostly in the liver and lung ${ }^{2}$. Humans are accidental intermediary hosts in the biological cycle of hy- datid disease. They are infected directly from a dog bite or indirectly by drinking water or eating food contaminated with the eggs of the parasite ${ }^{24}$. The disease is rarely seen in the vertebral system, occurring at a rate of $0.2-1 \%{ }^{1,45)}$. Cysts are usually seen in highly vascularized parenchymal organs such as

\footnotetext{
- Received : September 9, 2017 •Revised : November 28, 2017 •Accepted : April 25, 2018

- Address for reprints : Murat Zaimoglu, M.D.

Department of Neurosurgery, Ankara University School of Medicine, Sihhıye, Ankara 06230, Turkey

Tel : +90 31250823 00, Fax : +90 31231063 71, E-mail : m.zaimoglu.neurosurgery@gmail.com
}

This is an Open Access article distributed under the terms of the Creative Commons Attribution Non-Commercial License (http://creativecommons.org/licenses/by-nc/4.0) which permits unrestricted non-commercial use, distribution, and reproduction in any medium, provided the original work is properly cited. 
the brain, the liver, and the lung. Bone involvement is very rare. In our population, spinal hydatid cysts have become a challenge. The spongy part of the vertebral body seems to be one of the preferred sites. The pathological mechanisms remain unclear; hence, the surgical removal usually becomes problematic.

Obviously simple cyst puncture is not a solution. It is undetectable through which compartments in the vertebrae the scolex moves. Spinal hydatid cyst disease has high rates of morbidity, recurrence, and mortality. It is vital to excise the cyst together with its wall without rupturing it in the treatment. Rupture of the cyst may result in dissemination and chronic recurrence ${ }^{30)}$. There are several published studies about spinal hydatid cysts ${ }^{15,26,32,34)}$. To our knowledge, this is the largest Turkish study in the English literature on this subject. Here, in the context of the relevant literature, spinal hydatid cysts, multiple operations, chronic recurrences, and spinal hydatid cyst excision methods are discussed.

\section{MATERIALS AND METHODS}

Twelve spinal hydatid cyst cases were operated 29 times between 2005 and 2016. They were followed up clinically and radiologically for an average of 6.5 years (1-13). Their medical records and radiological investigations were reviewed retrospectively. Every patient is operated and cyst excision is performed. Patients are operated 1-6 times. In total, 29 operations are performed.

\section{Types of surgery}

\section{Decompression}

According to the localization of the cysts, a posterior or an anterior approach can be used. This method is preferred when the patient's condition is not good or performing MR is contraindicated. It is a palliative surgical method. It is not advised to use this method alone. Cyst rupture and distant organ metastasis is common. When cyst rupture occurs, it is possible that the disease progresses locally even to the subcutaneous tissue.

\section{Cyst removal}

The cyst alone is removed. This surgery is indicated if the cyst is localized in the epidural space without bone or dural involvement. If the dura is attached to cysts, dural excision and duroplasty must be performed. Usually laminectomy is performed. All patients are evaluated for systemic infection. Serologic tests and clinical examinations are performed for all patients. Magnetic resonance imaging (MRI) and computed tomography (CT) scan is used for all patients in pre-operative period and in follow up. Post-operative pathological analysis is performed for all patients. All patients were administered Albendazole treatment.

\section{RESULTS}

Of the 12 cases, six were males (mean age, 46.2 years) and six were females (mean age, 28 years). The overall mean age was 37.5 years. Eight patients lived in a rural environment, while four lived in an urban setting. The time from onset of symptoms to diagnosis was on average 3 months. In all patients, the initial clinical symptoms and signs were spinal. Motor or sensory deficits or altered reflexes were present in all patients. Seven of the patients had systemic hydatid cysts involving, for instance, the liver, lung or kidney. The characteristics of the patients are summarized in Table 1.

A preoperative analysis with CT scan and MRI is necessary. The number of segments involved and which columns of vertebrae are compromised must be determined. Spinal hydatid cyst disease is symptomatic when multiple segments and more than one vertebral column are corrupted. Extravertebral involvement can be identified with radiologic examination. The thorax and abdomen may be widely infected with the disease.

All patients are kept under routine follow up. As recurrences are common radiologic and clinical examination results are stored (Figs. 1-4). For all patients, posterior decompression with laminectomy, curettage of the lesion, aspiration of necrotic tissue, and drainage and washout of paravertebral cyst cavities is performed. Albendazole (400 mg p.o.) is administered twice daily for all patients. Medical treatment is started before the first surgery. Intraoperatively, the gauzes and cotton pads were soaked with hypertonic saline (3\%). Intraoperatively, the wound was washed with hypertonic saline.

There were seven stabilization procedures with laminectomies. Over the follow-up period, eight patients underwent more than one operation for the disease $(75 \%)$. Vertebral 
Table 1. Properties of patients with spinal hydatid cyst disease

\begin{tabular}{|c|c|c|c|c|c|c|c|c|}
\hline Patient No. & Age & Gender & $\begin{array}{c}\text { Neurological } \\
\text { deficit }\end{array}$ & Localization & $\begin{array}{l}\text { Systemic } \\
\text { infection }\end{array}$ & $\begin{array}{c}\text { Extradural space and } \\
\text { Paravertebral area } \\
\text { involvement }\end{array}$ & $\begin{array}{c}\text { Operated } \\
\text { numbers } \\
\text { (times) }\end{array}$ & $\begin{array}{l}\text { Followed-up } \\
\text { (months) }\end{array}$ \\
\hline 1 & 50 & $M$ & + & Sacral & + & + & 3 & 64 \\
\hline 2 & 14 & $\mathrm{~F}$ & + & Thoracal & - & - & 1 & 10 \\
\hline 3 & 54 & M & + & Odontoid & + & + & 3 & 70 \\
\hline 4 & 45 & F & + & Thoracal & - & + & 6 & 130 \\
\hline 5 & 38 & F & + & Lumbar & + & - & 3 & 68 \\
\hline 6 & 42 & M & + & Cervical & + & + & 2 & 95 \\
\hline 7 & 58 & M & + & Thoracal & + & + & 4 & 156 \\
\hline 8 & 32 & M & + & Lumbar & - & - & 1 & 32 \\
\hline 9 & 32 & $\mathrm{~F}$ & + & Sacral & - & - & 1 & 20 \\
\hline 10 & 9 & F & + & Thoracal & + & - & 2 & 36 \\
\hline 11 & 45 & $\mathrm{~F}$ & - & Sacral & - & + & 1 & 39 \\
\hline 12 & 44 & M & + & Thoracal & + & - & 2 & 46 \\
\hline
\end{tabular}

$M$ : male, $F$ : female
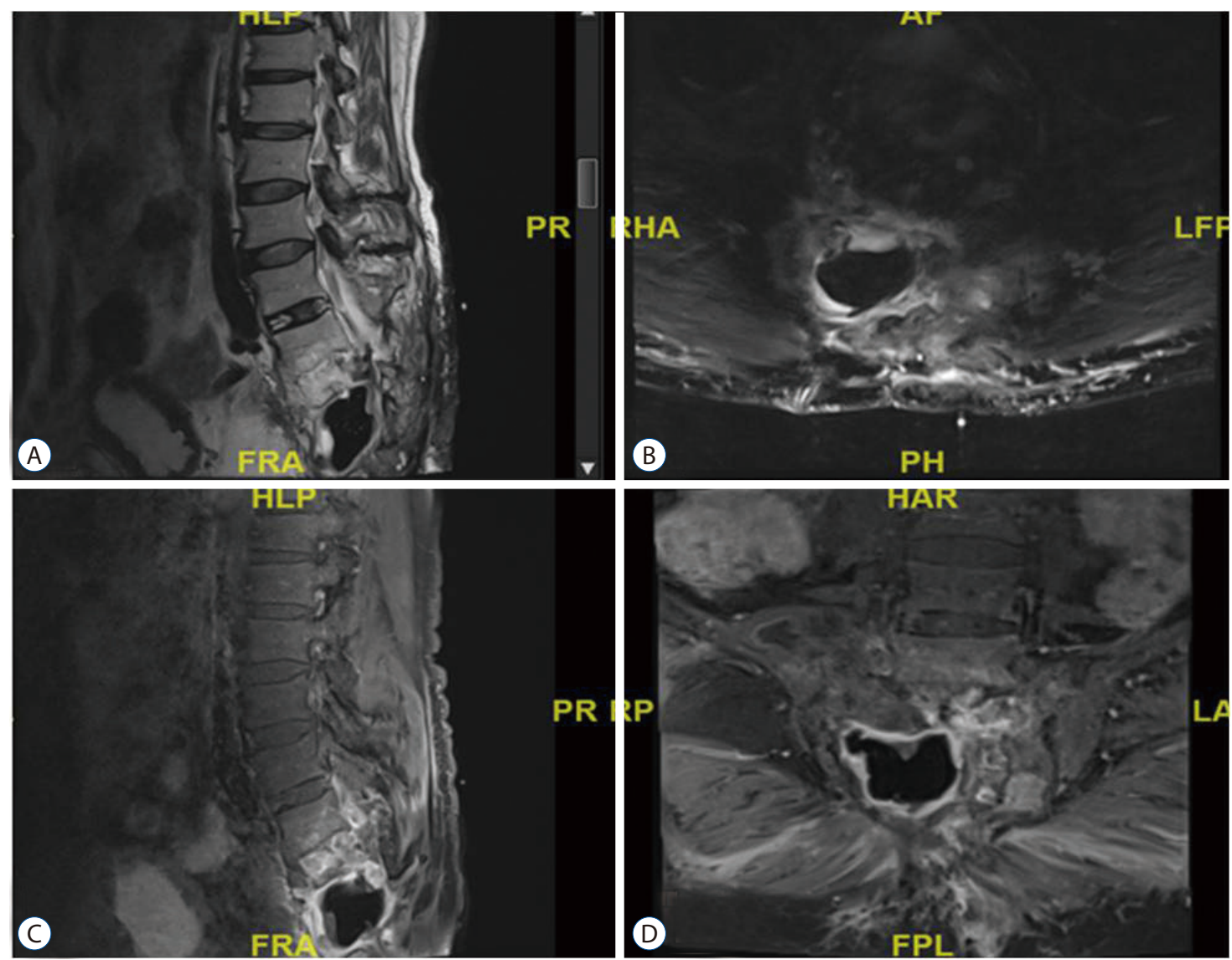

Fig. 1. Patient 11. A : Sagittal T2A weighted MRI showing sacral hydatid cyst infection. B : Sagittal T2A weighted MRI showing sacral hydatid cyst infection and paravertebral involvement. C : Contast enhanced sagittal T1A weighted MR. D : contast enhanced axial T1A weighted MR. MRI : magnetic resonance imaging, $\mathrm{MR}$ : magnetic resonance. 


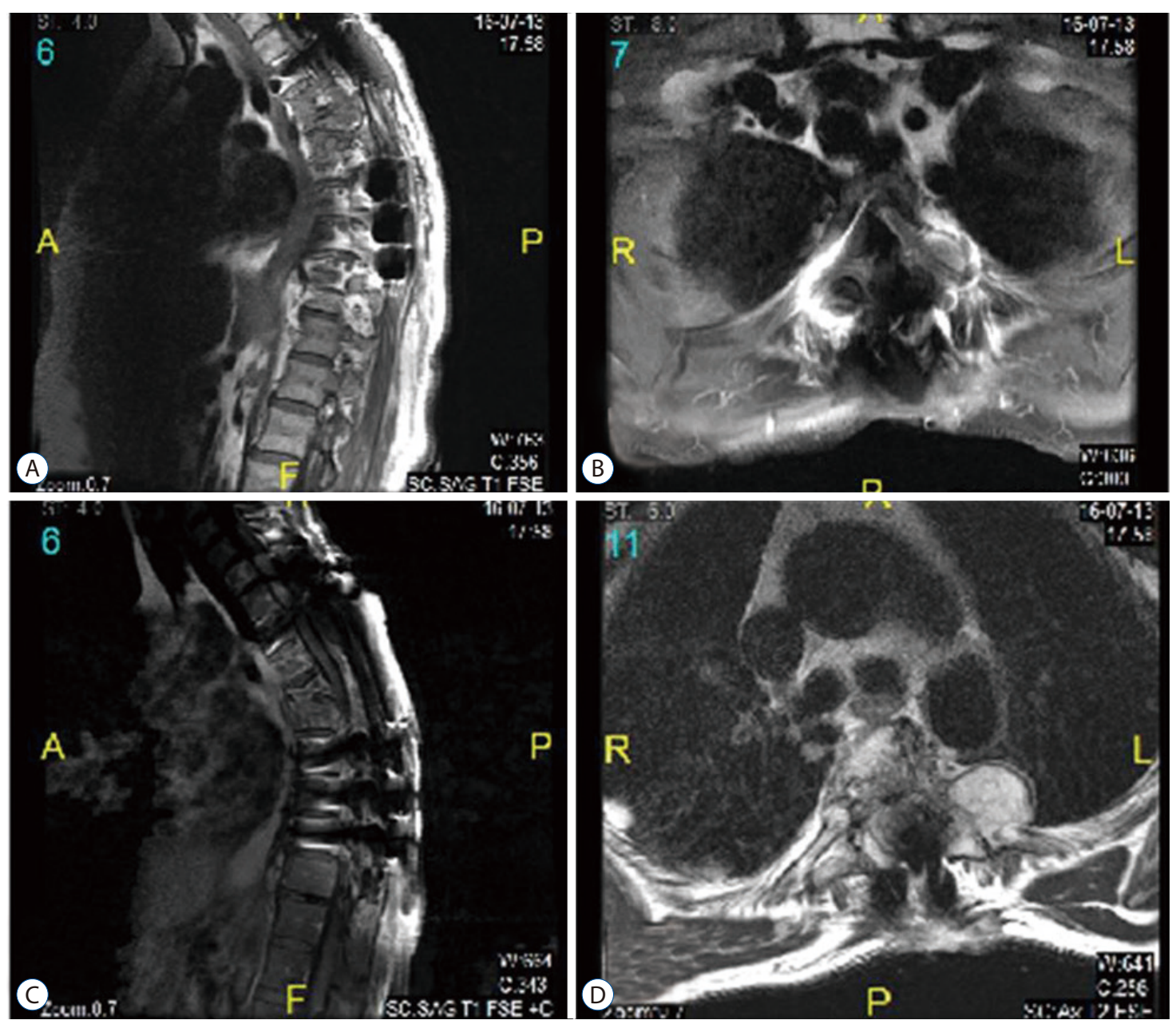

Fig. 2. Patient 7, thoracic hydatid cyst. Decompression and instrumentation surgery is performed. Recurrent disease can be seen in paravertebral area and subcutaneous tissue. A :T1A weighted sagittal MRI. B : Contrast enhanced T1A weighted sagittal MRI. C : Contrast enhanced T1A weighted sagittal MRI. D : T2A weighted axial MRI. R : right, L : left, MRI : magnetic resonance imaging.
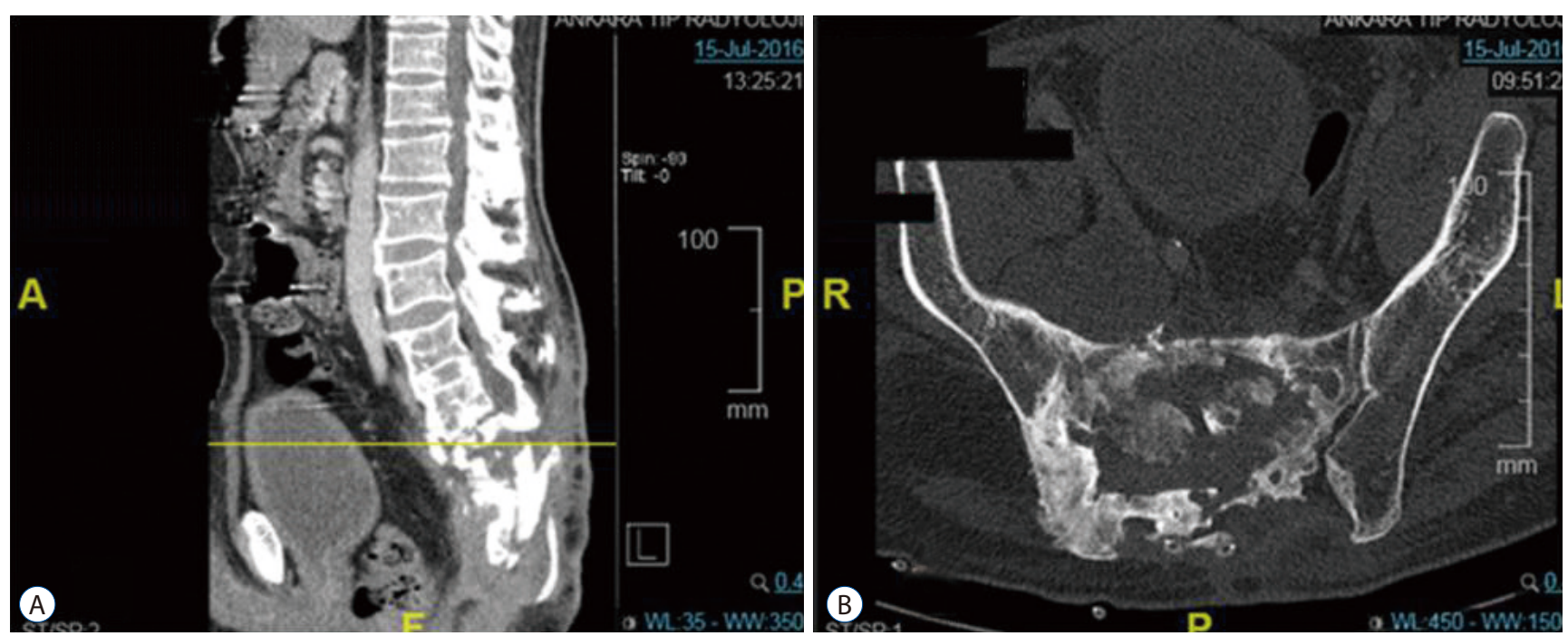

Fig. 3. Patient 1. Sagital (A) and axial computed tomography scan (B) of a sacral hydatid cyst patient, after 3rd operation. 


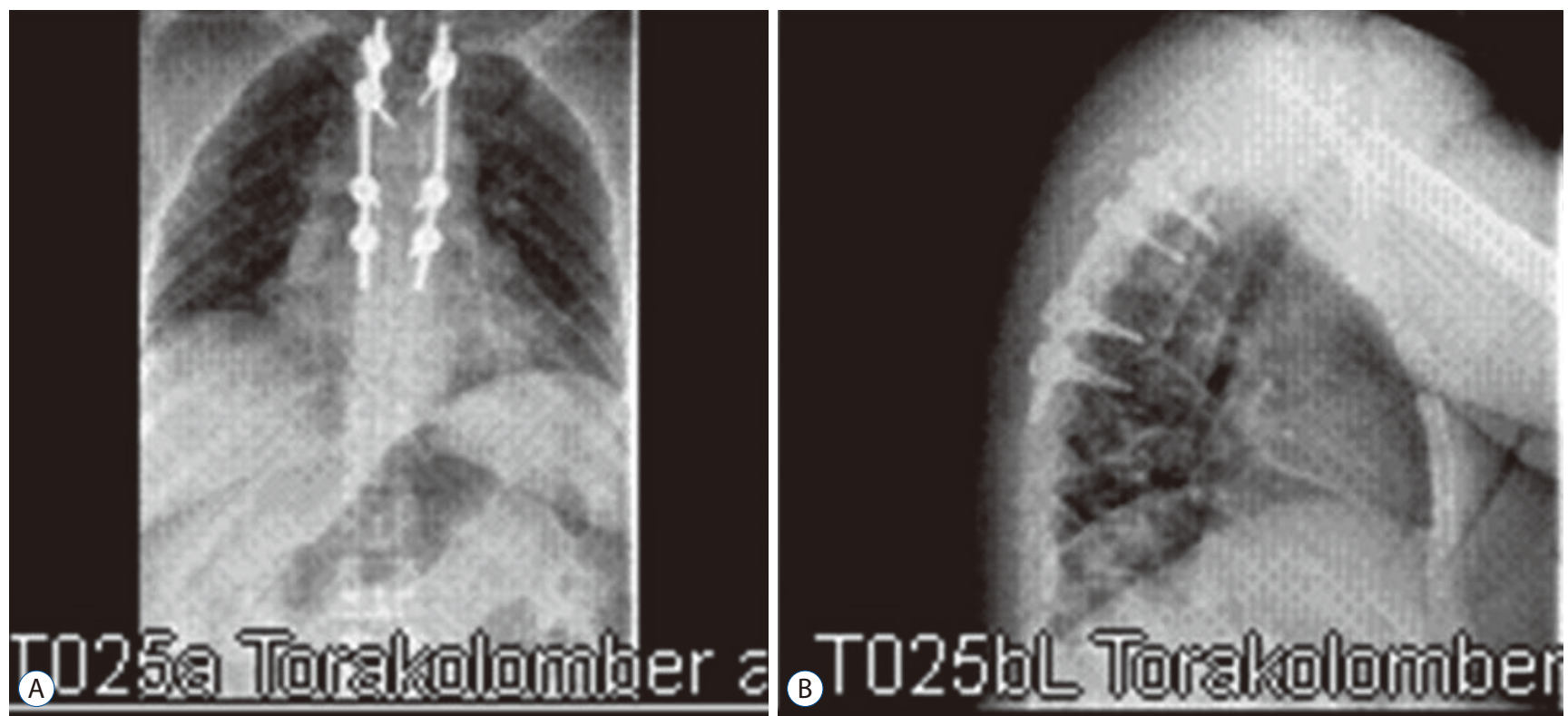

Fig. 4. Patient 4, X-Ray scan of a thoracic hydatid cyst patient. Spinal stabilization and laminectomy were performed. Antero-posterior (A) and lateral X-ray scan (B).

recurrences were universal. The average time for the first recurrence after surgery was 12 months. Five patients (42.5\%) had two or more vertebrae involved with the disease. At the time of diagnosis, six out of 12 patients had extravertebral involvement. There were three wound-healing problems, and one patient had temporary paraparesis after thoracic hydatid cyst resection.

\section{Surgical goals}

The goal of the surgery is to eradicate the cyst and scolex, although this objective is almost never achieved. Recurrences are common and the patient should be informed. Routine serologic, radiologic and clinical follow up should be advised.

The main goal of the surgery should be to resect the infected vertebrae in a craniocaudal fashion from healthy bone to healthy bone. After resection, a suitable method of vertebral stabilization should be applied. Repetetive surgeries should be foreseen and the surgeon should use as little stabilization material as possible.

\section{Continuous drainage of the cysts}

During surgery, the surgeon can place a two-way drainage catheter inside the cyst. During postoperative treatment, the cyst should be washed with chlorhexidine solution $(0.04 \%$ Chx-Glu) for 3 weeks.

In the figure, a patient lying on the bed is observed. The
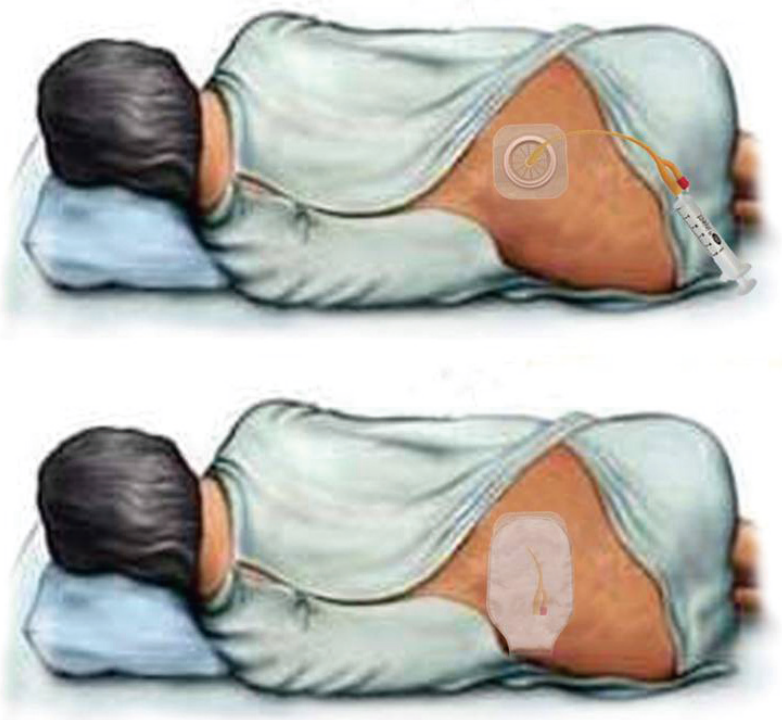

Fig. 5. Continuous drainage of the hydatid cyst.

drainage catheter is placed inside the cyst cavity of the patient. During cyst excision surgery, the surgeon can place the catheter proximal end inside the cavity, the distal end of the catheter is placed outside the patient. This two-way drainage catheter can be used to wash out the cavity after surgery. First chlorhexidine solution $(0.04 \% \mathrm{Chx}-\mathrm{Glu})$ is injected. After 5 minutes of washing, the solution and the cyst content is emptied from the catheter exit. To the best of our knowledge, this is the first study emphasizing the use of a two way catheter to 
Table 2. Spinal hydatid cyst disease cases in literature

\begin{tabular}{|c|c|}
\hline Study & No. of patients \\
\hline laroslavskii ${ }^{18)}(1956)$ & 1 \\
\hline Islekel et al. ${ }^{19)}$ (1998) & 1 \\
\hline Honma et al. ${ }^{17)}(1982)$ & 1 \\
\hline Gaucher et al. ${ }^{13)}$ (1983) & 1 \\
\hline Pamir et al...$^{34)}$ (1984) & 11 \\
\hline Claudon et al.9) (1987) & 2 \\
\hline Kunze et al. ${ }^{27)}$ (1992) & 1 \\
\hline Merkle et al. ${ }^{28)}(1997)$ & 4 \\
\hline Savas et al. ${ }^{39)}$ (1999) & 1 \\
\hline Reuter et al. ${ }^{38)}(2000)$ & 1 \\
\hline Toussaint et al. ${ }^{44)}$ (2001) & 1 \\
\hline Scheuring et al. ${ }^{40)}$ (2003) & 1 \\
\hline Georges et al. ${ }^{14)}(2004)$ & 2 \\
\hline Kadioglu et al. ${ }^{22)}$ (2005) & 1 \\
\hline Sengul et al. ${ }^{411)}$ (2008) & 1 \\
\hline Nell et al. ${ }^{29)}(2011)$ & 1 \\
\hline Piarroux et al. ${ }^{37)}$ (2011) & 3 \\
\hline Keutgens et al. ${ }^{25)}$ (2013) & 1 \\
\hline Abdelhakim et al. ${ }^{2)}$ (2014) & 1 \\
\hline Nourrisson et al. ${ }^{31)}$ (2014) & 1 \\
\hline Somay et al. ${ }^{42)}$ (2014) & 1 \\
\hline Dogan et al. ${ }^{10)}(2015)$ & 1 \\
\hline Atalan et al. (2016) & 1 \\
\hline Jain et al. $^{20)}(2014)$ & 3 \\
\hline Faucher et al..'2) (2017) & 1 \\
\hline Gezercan et al. ${ }^{15)}$ (2017) & 8 \\
\hline Agnihotri et al." (2017) & 1 \\
\hline Unal et al. ${ }^{46)}(2017)$ & 1 \\
\hline Cheng $^{8)}(1979)$ & 1 \\
\hline Vizcarra et al. ${ }^{47)}$ (2017) & 1 \\
\hline This study & 12 \\
\hline
\end{tabular}

wash out the cyst cavity (Fig. 5).

\section{DISCUSSION}

Spinal hydatid cyst disease is an endemic disease generally seen in the Mediterranean and Middle East countries ${ }^{1,2,16,35)}$. Spinal hydatid cyst disease is a rare and hard to treat disease. There are only a few articles in the literature worldwide (Table
2). Though mostly thoracic vertebral involvement is observed, cervical, lumbar, and sacral hydatid cysts can also occur ${ }^{2,734-36)}$. Odontoid process involvement is extremely rare ${ }^{6)}$. Among our cases, there were five thoracic vertebral, two cervical vertebral (one odontoid), and five lumbosacral vertebral cases. In six cases, there was extradural space and paravertebral area involvement, as summarized in Table 1. For diagnosis, physical examination and radiological studies such as CT and MRI scans are helpful. Serologically enzyme-linked immunosorbent assay, Western blot, indirect hemagglutination tests, and polymerase chain reactions are generally used for diagnosis ${ }^{10)}$. Depending on the disease localization, the goal of the surgery is decompression of spinal cord and - if necessary — stabilization of the spinal column to compensate for loss of stability as a result of cyst excision ${ }^{30)}$. We performed laminectomies and cyst excision in all cases, but six of them needed to be stabilized. Although it is known that albendazole alone cannot ensure recovery or prevent recurrence, when used as an ancillary application in inoperable patients or together with surgical treatment, it is useful in preventing or delaying recurrence or preventing intraoperative dissemination of the $\mathrm{cyst}^{30)}$. Before the resection, to prevent further spread secondary to cyst rupture, a cysticidal agent (hypertonic 30\% saline, cetrimide, or $70-95 \%$ ethanol) can be administered topically to destroy the cysts $^{32)}$. We administered hypertonic saline in all cases during the operation before and after cyst excision. The recurrence rate has ranged from $30 \%$ to $100 \%{ }^{5,11)}$. Recurrence was seen in nine cases $(75 \%)$ in our series.

Gezercan et al. ${ }^{15)}$ reported that even in patients who had a successful operation, recurrences are common. Long term follow up including serologic, clinical and radiologic tests should be performed. In our series, the results are parallel. In 12 reported cases, multiple operations are common. To add on, extradural space and paravertebral area involvement is seen in six patients.

Due to the multivesicular and more invasive nature of spinal hydatid cysts, their treatment method might be more difficult compared to that of intracerebral hydatid cysts. Subtotal excision and rupture of the cyst result in higher rates of recurrence $^{33)}$. Spinal hydatid cysts are classified into five categories for radiological purposes : intramedullar, intradural, extramedullar, extradural vertebral hydatid cysts, and paravertebral lesions ${ }^{23)}$. We had eight extradural hydatid cyst cases with paravertebral involvement, one intradural case ${ }^{23)}$ and one case 
with only dural invasion. Neither surgical nor medical treatment is generally efficient in cases with bone involvement. Although the hydatid cyst is characterized as benign pathology, in consequence of its local growing pattern, it can be classified in the malign group because of its high potential for dissemination, which can result in high incidence of recurrences $^{15,21,22,43)}$.

Spondylectomy can also be recommended for the treatment of cases accompanied by vertebral involvement; however, diseases frequently recur and become chronic ${ }^{11)}$.

\section{CONCLUSION}

Although spinal hydatid cyst disease is a benign pathology and is rarely seen, treatment should be aggressive and include total excision of the cyst without rupture, decompression of spinal cord, flushing of the area with scolicidal drugs, and ensuring spinal stabilization.

The surgeon dealing with spinal hydatid cyst infection should remember to administer albendazole treatment before surgery. Secondary wound infection is the most common morbidity after surgery. Postoperative antibiotics and wound care should be applied with utmost care. Recurrences are common for all spinal hydatid cyst patients. Routine radiologic and clinical follow up is necessary.

\section{CONFLICTS OF INTEREST}

No potential conflict of interest relevant to this article was reported.

\section{INFORMED CONSENT}

Informed consent was obtained from all individual participants included in this study.

\section{References}

1. Abbassioun $\mathrm{K}$, Amirjamshidi A : Diagnosis and management of hydatid cyst of the central nervous system: Part 2: Hydatid cysts of the skull, orbit, and spine. Neurosurg Q 11 : 10-16, 2001

2. Abdelhakim K, Khalil A, Haroune B, Oubaid M, Mondher M : A case of sacral hydatid cyst. Int J Surg Case Rep 5 : 434-436, 2014

3. Agnihotri M, Goel N, Shenoy A, Rai S, Goel A : Hydatid disease of the spine: a rare case. J Craniovertebr Junction Spine 8 : 159-160, 2017

4. Atalan G, Sivrioglu AK, Sönmez G, Celik M, Simsek B : A case of alveolar echinococcosis presenting as cerebral and spinal intradural metastases. Eurasian J Med 48 : 149-152, 2016

5. Bettaieb A, Khaldi M, Ben Rhouma T, Touibi S : Spinal echinococcosis; clinical study of 32 cases (author's transl). Neurochirugie 24 : 205210, 1978

6. Caglar S, Bozkurt M, Kahilogullari G, Ozdemir M : Management of a rare and dangerous infectious lesion: hydatid cyst disease of the odontoid process. WScJ $3:$ :29-32, 2012

7. Celik C, Münevver FS, Ucan $H$ : Spinal hydatid cyst: review. Türkiye Klinikleri J Med Sci 30 : 1073-1077, 2010

8. Cheng GY : Hydatid cysts of the spinal canal. Zhonghua Fang She Xue Za Zhi 13 : 48-49, 1979

9. Claudon M, Bracard S, Plenat F, Regent D, Bernadac P, Picard L : Spinal involvement in alveolar echinococcosis: assessment of two cases. Radiology 162 : 571-572, 1987

10. Dogan I, Kahilogullari G, Guner E, Unlu A : A rare and unexpected clinical progress and location on a primary extradural spinal hydatid cyst in a pediatric patient: a case report. Childs Nerv Syst 31 : 1407-1411, 2015

11. Fares Y, Khazım R, El Zaatiri MM, Haddad GF, Barnes PR : Spinal hydatid disease and its neurological complications. Scand J Infect Dis 35 : 394-396, 2003

12. Faucher JF, Descotes-Genon C, Hoen B, Godard J, Félix S, Aubry S, et al. : Hints for control of infection in unique extrahepatic vertebral alveolar echinococcosis. Infection 45 : 365-368, 2017

13. Gaucher A, Vinet E, Pere P, Plenat F, Ethgen D, Pourel J : Alveolar echinococcosis with spinal localization. Presse Med $12: 1366,1983$

14. Georges S, Villard O, Filisetti D, Mathis A, Marcellin L, Hansmann Y, et al. : Usefulness of PCR analysis for diagnosis of alveolar echinococcosis with unusual localizations: two case studies. J Clin Microbiol 42 : 5954-5956, 2004

15. Gezercan Y, Ökten Al, Çavuş G, Açık V, Bilgin E : Spinal Hydatid Cyst Disease. World Neurosurg $108:$ :07-417, 2017

16. Herrera A, Martínez AA, Rodríguez I : Spinal hydatidosis. Spine (Phila Pa 1976) 30 : 2439-2444, 2005

17. Honma K, Basano N, Andoh N, Iwai K : Hepatic alveolar echinococcosis invading pancreas, vertebrae, and spinal cord. Hum Pathol 13 : 944 946, 1982

18. Iaroslavskii VE : Primary alveolar echinococcosis of spinal canal. Sov Med $20: 81-83,1956$

19. Işlekel S, Erşahin Y, Zileli M, Oktar N, Oner K, Ovül I, et al. : Spinal hydatid disease. Spinal Cord $36: 166-170,1998$

20. Jain S, Jaiswal M, Gandhi A, Mittal RS : Primary spinal alveolar hydatid disease: a case series with review of literature. WScJ 5 : 12-20, 2014 
21. Jaiswal $S$, Jaiswal $A K$, Jain $M$, Behari S, Pandey $R$ : Primary spinal extradural hydatid cyst causing paraplegia. Indian J Pathol Microbiol 52 : 432-433, 2009

22. Kadioglu HH, Malcok UA, Senguli G, Aydin IH : Alveolar hydatid disease of the spine causing paraplegia. Neurosciences (Riyadh) $10: 180$ 182, 2005

23. Kahilogullari G, Tuna H, Aydin Z, Colpan E, Egemen N : Primary intradural extramedullary hydatid cyst. Am J Med Sci 329 : 202-204, 2005

24. Karray S, Zlitni M, Fowles JV, Zouari O, Slimane N, Kassab MT, et al. : Vertebral hydatidosis and paraplegia. J Bone Joint Surg Br 72 : 8488, 1990

25. Keutgens A, Simoni P, Detrembleur N, Frippiat F, Giot JB, Spirlet F, et al. : Fatal alveolar echinococcosis of the lumbar spine. J Clin Microbiol 51 : 688-691, 2013

26. Kılşç C, Demirkazık M, Boyar B, Akalan N, Erdem H : Spinal kist hidatikler. Türk Nöroşirürji Dergisi Ek 1 : 62-64, 1989

27. Kunze $V$, Layer $G$, Brüning $R$, Nägele $M$ : "Metastasizing" echinococcus alveolar of the liver. Radiologe 32 : 444-447, 1992

28. Merkle EM, Kramme E, Vogel J, Krämer S, Schulte M, Usadel S, et al. : Bone and soft tissue manifestations of alveolar echinococcosis. Skeletal Radiol 26 : 289-292, 1997

29. Nell M, Burgkart RH, Gradl G, von Eisenhart-Rothe R, Schaeffeler C, Trappe D, et al. : Primary extrahepatic alveolar echinococcosis of the lumbar spine and the psoas muscle. Ann Clin Microbiol Antimicrob $10: 13,2011$

30. Neumayr A, Tamarozzi F, Goblirsch S, Blum J, Brunetti E : Spinal cystic echinococcosis--a systematic analysis and review of the literature: part 2. Treatment, follow-up and outcome. PLoS Negl Trop Dis 7 : e2458, 2013

31. Nourrisson C, Mathieu S, Beytout J, Cambon M, Poirier P : Osteolytic bone lesion: vertebral alveolar echinococcosis in a patient with splenectomy. Rev Med Interne 35 : 399-402, 2014

32. Onal C, Canbolat A, Gokay H, Kaya U, Turker K, Turantan M, et al. : Spinal hidatik kistler. Türk Nöroşirürji Dergisi Ek 5 : 34, 1992

33. Ozdemir HM, Ogün TC, Tasbas B : A lasting solution is hard to achieve in primary hydatid disease of the spine: long-term results and an overview. Spine (Phila Pa 1976) 29 : 932-937, 2004

34. Pamir MN, Akalan N, Ozgen T, Erbengi A : Spinal hydatid cysts. Surg
Neurol $21: 53-57,1984$

35. Papanikolaou A : Osseous hydatid disease. Trans R Soc Trop Med Hyg $102:$ 233-238, 2008

36. Patel D, Shukla $D$ : Back bugged: A case of sacral hydatid cyst. J Neurosci Rural Pract $1:$ 43-45, 2010

37. Piarroux M, Piarroux R, Giorgi R, Knapp J, Bardonnet $K$, Sudre $B$, et al. : Clinical features and evolution of alveolar echinococcosis in France from 1982 to 2007: results of a survey in 387 patients. J Hepatol 55 : 10251033, 2011

38. Reuter S, Seitz HM, Kern P, Junghanss T : Extrahepatic alveolar echinococcosis without liver involvement: a rare manifestation. Infection 28 : 187-192, 2000

39. Savas R, Calli C, Alper H, Yunten N, Ustün EE, Ertuğvrul G, et al. : Spinal cord compression due to costal Echinococcus multilocularis. Comput Med Imaging Graph 23 : 85-88, 1999

40. Scheuring UJ, Seitz HM, Wellmann A, Hartlapp JH, Tappe D, Brehm K, et al. : Long-term benzimidazole treatment of alveolar echinococcosis with hematogenic subcutaneous and bone dissemination. Med Microbiol Immunol 192 : 193-195, 2003

41. Sengul G, Kadioglu HH, Kayaoglu CR, Aktas S, Akar A, Aydin IH : Treatment of spinal hydatid disease: a single center experience. J Clin Neurosci $15: 507-510,2008$

42. Somay H, Ayan E, Turk CC, Emon ST, Berkman MZ : Long-term disseminated recurrence in spinal hydatid cyst: a case report. Turk Neurosurg $24: 78-81,2014$

43. Song $X$, Liu $D$, Wen $H$ : Diagnostic pitfalls of spinal echinococcosis. J Spinal Disord Tech 20 : 180-185, 2007

44. Toussaint F, Pere P, Le Chaffotec L, Grandhaye P, Pourel J, Chary-Valckenaere I: Alveolar echinococcosis of the spine. J Clin Rheumatol 7 : 248-251, 2001

45. Turgut $M$ : Hydatid disease of the spine: a survey study from Turkey. Infection 25 : 221-226, 1997

46. Unal VM, Ozdemir N, Karadag A, Oguzoglu S, Celik H : Primary sacral hydatid cyst causing cutaneous fistula. J Coll Physicians Surg Pak 5 : 311-312, 2017

47. Vizcarra $M$, Mujica $M$, Sánchez V, Méndez $P$ : An adolescent with lumbosacral instability due to the presence of a hydatid cyst: a case report. Rev Peru Med Exp Salud Publica 34 : 126-131, 2017 